\title{
Forming divine bodies in the Hebrew Bible
}

\author{
DANIEL O. McCLELLAN
}

A number of publications in recent years have significantly strengthened the case that the biblical texts consistently conceptualize an embodied deity. There is frequently a tendentiousness accompanying the relevant scholarship, however, which perdures for a number of reasons. Among the most salient of these is the embeddedness of a dichotomous view of deity and humanity. Rudolph Otto famously developed a theoretical framework for the holy around the conceptualization of deity as das ganz Andere, or 'the wholly other' (Otto 1917). Otto did not innovate this view of deity, but he and others have helped it become firmly entrenched within biblical scholarship's methodological foundations, and it has become one of the most significant obstacles to a more robust and productive understanding of biblical conceptualizations of deity, particularly of divine bodies. While a number of publications have significantly advanced the discussion regarding the conceptualization of embodied deity (especially Hamori 2008; Sommer 2009; Wagner 2010; Knafl 2014; Smith 2015; Markschies 2016), much of that discussion remains anchored to ontological frameworks and to theological systematization.

These methodological anchors prioritize clear lines of demarcation and in many ways endure because they support the structuring of values and power within the academy and the church or synagogue. In an effort to spur this discussion into more productive spaces, this chapter will apply social and cognitive lenses to this line of enquiry, interrogating the ways cognitive ecologies and predispositions influenced and informed the conceptualization of divine embodiment and the curation of its socio-material manifestations. The discussion will settle on two specific manifestations of presencing media: the ark of the covenant and the written Torah.

Throughout this chapter, I will make an important distinction between intuitive reasoning and reflective reasoning. By these terms, I refer to two types of reasoning that occupy a spectrum of cognition. Intuitive reasoning is automatic, subconscious and rapid and is more closely linked with our cognitive architecture and conditioning. Reflective reasoning is slower, more deliberate and more directly based on conscious reasoning (Evans and Frankish 2009; Oviedo 2015; Morgan 2016). The two frequently come into conflict, resulting in two general types of resolutions (Järnefelt, Canfield and Kelemen 2015; Pennycook, Fugelsang and Koehler 2015). Decoupling is the process by which an intuitive response is constrained or overridden by reflective reasoning (for instance, when initial alarm at noises in our home at night is ameliorated by the conclusion that it must be the house settling). Rationalization is the process by which the person applies reflective 
reasoning to the justification, explanation or elaboration of an intuitive response (for instance, when our tribalism compels us to justify voting for an immoral or unfit candidate for office because we belong to the same political party). Understanding the distinction of the two types of cognition can help us to more carefully parse socioculturally contingent reflective explanations and accounts of deity from the far more consistent underlying intuitive motivations.

\section{Bodies, human and divine}

There are a number of different dimensions involved in today's conceptualizations of the human 'body', but in broad terms, we intuitively understand the body to be the primary visible and material locus of a person's identity and agency. Now, that is not to identify the body with a person's agency or identity, it is only to say the body is where a person's agency and identity are intuitively located. We also intuitively understand these different elements of personhood to be separable from the body in certain circumstances, and even to be capable of permeating other bodies. This is why stories about things like minds switching bodies, multiple identities inhabiting bodies, and spirits possessing and controlling bodies are so common - they rely on intuitive reasoning about agency and bodies. This has direct relevance to how the Hebrew Bible represents the formation and curation of divine bodies, but some unpacking is necessary for a fuller picture.

To be perhaps recklessly succinct, our evolutionary history and cognitive architecture predispose us to think of our bodies as containers for the separable loci of our selves (Sharifian et al. 2008: 3-24; Chudek et al. 2017). This is not to assert ontological binaries or a Cartesian conceptualization of the self but to refer to the ubiquitous conceptual metaphor THE BODY IS A CONTAINER, which frames our understanding of the body according to the notion of internal and external spaces mediated by a boundary that can have varying degrees of permeability and extension inward and/or outward. Cognitive and anthropological research suggest the CONTAINER image schema naturally starts developing in preverbal infant cognition (Mandler 1992; Tilford 2017: 17, 23). As we grow, have more and more experiences in the world and participate in discourse about ourselves and the world around us, we get a sense for interiority and exteriority - things are put into our bodies and things come out of our bodies - and we recognize that our skin functions in numerous ways as a boundary that separates us from the world around us and keeps the things inside us on the inside, and the things outside us on the outside.

This conceptual metaphor also influences other reasoning about our sense of self. Because injury to parts of the body like the head, the chest and the abdominal region tend to be the most life-threatening, these regions and the organs within them have become highly salient to our concepts of self and have become identified in societies around the world with internal loci of agency, cognition, emotion and animation (Sharifian et al. 2008; Berendt and Tanita 2011). As an example, in the Western world today, the heart is commonly identified as the seat of emotion, while the brain is identified as the seat of intelligence. These associations contribute to the common motif of one's heart and brain being in conflict with each other. The general autonomy of these loci of agency and cognition also contributes to stories about brains being surgically implanted in other bodies, or people feeling reunited with a deceased loved one by listening to the heartbeat of a recipient of that loved one's donor heart (Earl 2015). In certain circumstances, these loci can intuitively reify identity on their own. 
Death raises another influential dynamic. Bodies die and observably deteriorate, but we do not intuitively perceive the body to be strictly coterminous with the person. The loci of their agency and identity are often perceived to be separate, so it can take that intuitive cognition some time to restructure our perceptions and expectations regarding the presence and agency of deceased loved ones (Bennet and Bennett 2000; Keen, Murray and Payne 2013). As a result, we might feel they are still with us or 'out there' in some way. This contributes to the perception attested across cultures that unseen and socioculturally curated loci of cognition, animation and agency can survive the deterioration of the body (Bering 2002; Bering, McLeod and Shackelford 2005). In Western cultures, among the most salient of these loci are the mind, the soul and the spirit (Bering 2006; Roazzi, Nyhof and Johnson 2013). These intuitions about unseen loci of agency and their continuation after death lead to sociocultural elaborations such as disembodied spirits, spirit possession, out-of-body experiences and reincarnation (Cohen 2008; Cohen and Barrett 2008; Craffert 2015). This unseen agency is usually conceptualized ambiguously and inconsistently, even within these culturally conventional frameworks, but material media provide a tangible, visible locus for engagement. This is connected with a phenomenon that provides a helpful segue into discussions of divine bodies: the 'animated' gravestone. Even in thoroughly secularized societies, people commonly speak with the dead, and gravestones, in particular, often function to facilitate and focus these discussions. As Elizabeth Hallam and Jenny Hockey explain,

The highly personalized graves of loved ones have been transformed into spaces in which the 'living' deceased reside and receive visitors and gifts ... The headstone is, in a sense, animated as the body of a person in that it is washed, cared for, gazed at, dressed with flowers, offered drinks, and surrounded by household and garden ornaments. (Hallam and Hockey 2001: 151)

In the ancient world, mortuary spaces performed much the same functions. Meals were provided for the deceased and shared with the deceased, while stelae served as proxy bodies for the unseen agency of the deceased. One of the clearest articulations of this framework was found in the so-called mortuary chapel of Katumuwa at Sam'al (Sanders 2013; Herrmann and Schloen 2014; Steiner 2015). The space included a stele that depicts Katumuwa in a banquet scene and is inscribed with a text prescribing meal offerings for his $n b \check{s}$ ('self' or 'life'), which, according to the inscription, will be 'in this stele' (bnșb.zn). ${ }^{1}$ These meal offerings, associated with primary burial/memorialization and then repeated at intervals, were among a series of actions perpetuating the afterlife of the deceased through ritual memorialization. ${ }^{2}$ The inscription or utterance of the deceased's name was one of the most salient mechanisms for perpetuating their existence, as personal names were symbolic of identity and thus intuitively linked with agency. Where remains were inaccessible or buried at a distance, a stele or other ritual objects could host the deceased's locus of agency. Katumuwa's patron in life, Panamuwa, for instance, arranged for his own post-mortem welfare by having the following inscribed on a statue of Hadad that

\footnotetext{
${ }^{1}$ On the relationship of the Sam'alian $n b s$ to the Hebrew שפ, see Steiner (2015: 137-9).

${ }^{2}$ For archaeological evidence of meal offerings to the deceased in ancient Israel and Judah, see Bloch-Smith (1992: 218). These offerings appear to have played a role in maintaining social relationships with the dead of the household, as discussed by Stavrakopoulou (2016). While the Hebrew Bible prohibits offerings to the dead in some places (Ps. 106.28), in others it seems to treat them favourably or at least neutrally, as long as food offerings to YHWH do not come from the same source as offerings to the deceased (Deut. 26.14).
} 
was discovered at a cultic installation in Sam'al: '[May the $n$ ] bs of Panamuwa [eat] with you, and ma[y the $n b] s ̌$ of Panamuwa dri[nk] with you' (Donner and Röllig 2002: 49). As Matthew Suriano (2014: 403) states, 'The establishment of Panamuwa's mqm for his name and soul right beside (and along with) Hadad's stele insured that his defunct-soul would be fed so long as the storm god received food and drink offerings. ${ }^{3}$

Suriano's comment highlights the consonance between the treatment of the dead and the treatment of deities. ${ }^{4}$ Like deceased kin, deities had partible loci of agency and were provisioned through offerings made in special cultic installations and to cultic objects that functioned to presence the deities. Indeed, the care and feeding of deities is likely an elaboration on the care and feeding of deceased kin (Pyysiäinen 2009: 68; Barrett 2011: 103-4). Like deceased kin, deities were understood to be partible and permeable (Sommer 2009; Pongratz-Leisten 2011), but because divine bodies were unavailable for direct observation, there were fewer restrictions on the reflective reasoning about that partibility and permeability, as well as about the deterioration of divine bodies. Without these restrictions, divine bodies were still most commonly conceptualized in anthropomorphic terms, but they were thought to be far more durative, far less susceptible to damage, far more luminous and fantastical and, in many circumstances, far larger (Moore 1996; Hamori 2008: 129-49; Smith 2015). They were also distant and inaccessible, which meant some manner of materially accessible 'body' would have to be provided in order to reify and directly engage with the presence and agency of the deity.

\section{Forming divine bodies in ancient Southwest Asia}

The larger societies of ancient Southwest Asia developed a variety of material media for the presencing of deities and divine agency, but they reflect socioculturally mediated variations on very similar underlying themes. In general, these societies reflectively developed authoritative knowledge regarding certain materials that were considered appropriate or necessary for presencing deities and divine agency. These materials could be transformed through prescribed processes and by authorized agents into conventionalized types of cultic images, which could be 'animated' or 'enlivened' by the deity's presence through ritual acts.

The most explicit discussions of these rituals are limited to a few surviving Akkadian fragments from first millennium BCE Mesopotamia (Boden 1998; Walker and Dick 1999, 2001; McDowell 2015). The number and order of incantations and ceremonies differ between the surviving fragments, but the core of the process was the ceremonial washing of the mouth, which purified the image for contact with the deity, and the ceremonial opening of the mouth, ${ }^{5}$ which enabled the image to breathe, smell, eat and drink. As lines in the incantation preserved on the Sultantepe tablet (STT 200) illustrate, 'This

\footnotetext{
${ }^{3}$ Related conceptualizations of the material presencing of the deceased and their provisioning are found among elite burials in Egypt and Mesopotamia and are obliquely attested in the biblical texts; see further Asher-Greve (1997); Taylor (2001); Wyatt (2012); MacDougal (2014).

${ }^{4}$ As an example, the $m i s p \hat{\imath}$ and $p$ it $p \hat{\imath}$ rituals (discussed below) were used for the animating of divine images as well as cultic images of deceased kings, as discussed in Winter (1992); Walker and Dick (1999: 58); Machinist (2006). ${ }^{5}$ The opening of the mouth could also be performed for images representing living kings and other persons; see Walker and Dick (2001: 13).
} 
statue without its mouth opened cannot smell incense, cannot eat food / nor drink water' (Walker and Dick 1999: 96-100). ${ }^{6}$ Both the secondary references to the ritual and the ritual texts themselves use language and symbols related to gestation and birth (as well as manufacturing) as part of a lengthy ritual process involving a tamarisk trough, symbolic of a divine womb (the buginnu), which transitioned the deity into the cultic image. According to one text, after reciting an incantation that includes, 'Go, do not tarry', the performer 'makes (him) enter the form' (Walker and Dick 1999: 96-7). ${ }^{7}$ The Ninevite Ritual Text instructs the artisan to whisper 'into the ear(s) of that god', saying, " "You are counted among your brother gods"' (Walker and Dick 1999: 94-5). When the rituals associated with the liminal phase were complete, the image was installed in its temple and given its first meal.

Two aspects of these rituals to be highlighted are the materials used and the role of the artisan. Only certain materials were considered to have qualities that were appropriate for washing the image or that could facilitate the process of enlivenment (Hurowitz 2006; Benzel 2015). Even in their raw state, for instance, pure gold and silver do not oxidize, but maintain their colour and shine. This quality could very easily become associated with the brilliance and glory of deity and thus be conceptualized either as coming from divine realms or as a more pure or suitable habitation or conduit for divine agency/presence. This may account for the inclusion of gold and silver in the buginnu and the use of gold and silver plating over cultic images. While the core of the image was composed of wood, rather than precious metals, specific types of wood were still preferred. The tamarisk, called eșemti ili, 'bone of the gods', was probably most prominent (Hurowitz 2006: 5-6). ${ }^{8}$ If so, the use of a tamarisk buginnu and the inclusion of tamarisk in the mixture placed within it may have been intended to materially link the cultic image with the womb in which the precious materials gestated overnight.

While these materials could be considered divine in origin (scattered or hidden in the earth by the deities) or especially suited to transmitting or housing divinity, whether inherently or otherwise, certain acts were required (and demanded by the gods themselves) to commission them for divine inhabitation. The washing and opening of the mouth ceremonies transitioned the image from an earthly creation to a self-created divine entity, and some concomitant ritual was needed to signal the dissociation of the image from its natural/human origins. ${ }^{9}$ This would have amplified the perception of the image as inhabitable by divine agency and was accomplished most conspicuously through the

\footnotetext{
${ }^{6}$ As Walker and Dick (1999: 71) observe, while the opening of the mouth seems more critical to the process of enlivenment, it 'was evidently subordinated in the first millennium to the concept of mouth-washing'.

${ }^{7}$ While this may indicate the deity is compelled to inhabit the image, the Sumerogram Grš.hur.ME could also be read as the Akkadian gišhuru, which would be 'magic circle', reflecting the notion of the 'magic circles of the gods'; see Walker and Dick (1999: 81-2 n.81).

${ }^{8}$ McDowell (2015: 75) summarizes: 'The tamarisk from which the buginnu was made ... may have been understood both as a component of the divine statue's formation, perhaps its skeletal system, and as a cleansing and purifying agent, possibly for the womb and the gestating divine embryo.'

${ }^{9}$ Note the following comments from Pongratz-Leisten and Sonik (2015: 8):

The Greek term archeiropoieta ... identifies miraculous portraits or representations that were 'not made by any [human] hand', encompassing in the Christian tradition such images as the Mandylion (Image of Edessa). The archeiropoieta are not limited to this context, however; ancient Greek sources include various accounts of divine images that had miraculously appeared, having fallen perhaps from the heavens or yielded by the seas, and that were understood as products of the divine rather than human agency.
} 
symbolic amputation of the artisan's hands and declarations such as anäku lā ēpu[šs ...], '(I swear) I did not make (the statue)' (Walker and Dick 1999: 94-5). ${ }^{10}$

These rituals represent the most explicit reflective practices associated with the intuitive conceptualizations of divine agency as communicable and of certain inanimate objects and substances as animable by that agency. Variations in details, including the degree of independence of the image, the number of manifestations, the associations between the deities and the locations, and the types of materials used, are all products of diverse reflective considerations taking place within different socio-material ecologies. ${ }^{11}$ What is consistent is the intuitive perception of agency as communicable and of personhood as partible and permeable. These intuitions need not be explicitly manifested in praxis or in reflective rationalizations of that praxis in order for them to be influential, of course. Related rituals and conceptualizations of enlivened statues from other societies around the world and down to the present time demonstrate the transcultural and transhistorical intuitiveness of this approach to unseen agency. These conceptualizations do not stand in contrast or contradiction to intuitive notions of human personhood and agency but rather represent more flexible and dynamic elaborations on both (contra Sommer 2009: 195 n.145). The general intuitiveness and broad consistency of these conceptualizations across ancient Southwest Asia, along with significant overlap in rituals and traditions associated with deity, support the preliminary application of the same conceptual frameworks to the interrogation of the way divine bodies were formed in Iron Age Israel and Judah.

\section{Forming bodies in Iron Age Israel and Judah}

Although we have no direct attestation of prescriptions for animating rituals in the material remains from the regions inhabited by Iron Age Israel and Judah, there is a rich tradition in the region of materially representing and presencing deity that reaches back into Neolithic periods. In the Bronze and Iron Ages, this tradition drew from the same conventions and intuitive concepts of personhood and deity which were circulating in the surrounding cultures. ${ }^{12}$ Finds from Iron I-IIA that depict

\footnotetext{
${ }^{10} \mathrm{~A}$ similar 'opening the mouth' ritual is attested in a range of Egyptian texts. Its full name was 'Performing the Opening of the Mouth in the Workshop for the Statue of PN', but it could also be referred to as the 'Opening of the Mouth and the Eyes' or just 'Opening of the Mouth' (wpt-r or wn-r). See further Roth (1992); McDowell (2015: 85-109). For a comparison of the Mesopotamian and Egyptian rituals, see McDowell (2015: 109-15). There is also a relevant Hittite text from the late fifteenth or early fourteenth century BCE that prescribes an eightor nine-day regimen for commissioning a satellite cult installation for the 'Deity of the Night' (here the goddess Pirinkir); see further Beal (2002); Miller (2004: 259-311); Beckman (2010: 80-5). The process for installing the deity is long and complex, but on the fifth day, before leaving the old temple behind, the text in section 22 prescribes the following utterance: 'Honoured deity! Preserve your being, but divide your divinity! Come to that new house, too, and take yourself the honoured place!' (translation is from Miller 2004: 290). Niehr (1997: 78) notes related features of some Phoenician and Aramaic inscriptions: 'After a Phoenician temple had been built or restored, the divine statue had to be erected in the sanctuary. This is referred to with the phrase "I/we caused the deity to dwell in it" (yšb yiphil)'.

${ }^{11}$ The question of whether or not the image is a 'full' or 'partial' deity would have emerged situationally and would have been addressed within the relevant rhetorical contexts. There is no need to impose a systematic ontology onto the discussion.

${ }^{12}$ According to Keel and Uehlinger (1998: $\mathbb{S} \mathbb{S}$ IV-V), the material representation of deity in the highlands in the Late Bronze Age reflected heavy Egyptian influence, particularly in the prevalence of enthroned male Egyptian deities, and especially those who represented political domination and war. Bull imagery was particularly prominent, but while in earlier periods it could represent either fecundity or ferocity, by the Iron Age, it almost exclusively reflected the latter. The role of the goddess was diminished in Egypt, but southern Levantine artisans appear to have carried on a simplified version of a popular 'naked goddess' motif through the production of
} 
deity include stelae, metal statuary (usually from earlier periods), objects in stone, terracotta cult stands, model shrines, shrine-plaques, anthropomorphic terracotta vessels and figurines, worship scenes depicted on seals and depictions of deity in or on clay (Uehlinger 1997: 102-12). Metal statuary depicting male deities does not appear to have been produced - or at least not widely - from the tenth century BCE onwards, which has been taken as a sign of programmatic aniconism, but is more likely a shift in preference governed by the markets and available resources. As Tryggve Mettinger (1995) convincingly argues, Israel and Judah were initially simply carrying on a 'de facto aniconism' that had long been current throughout the broader West Semitic cultural milieu. This aniconism was not 'the result of theological reflection. Instead, it must be seen as an inherited convention of religious expression which only later formed the basis for theological reflection' (Mettinger 1995: 195). The more widespread use of symbols and substitute entities during this period suggests that a need for the cultic image to approximate the ostensible appearance of the deity itself was no longer especially salient (if it ever was). The priority was presencing the deity, not looking like it (cf. Ornan 2004).

While some of the depictions mentioned above may have had primarily commemoratory or dedicatory functions, many would have been widely understood to presence the deity or channel/transmit divine or otherwise supernatural agency, particularly if erected in a public setting and assigned a specific socio-material role in the functioning of the society. Such depictions no doubt represented a spectrum of deities running the gamut from deceased kin to socially concerned high deities. Among social elites, ancestral connections may have been asserted for those high deities. The archaeological bias towards the state and its elites has weighted our data overwhelmingly in favour of the few deities who predominated on a national or dynastic level, of course, so little may be said about the more private and personal end of that spectrum of deities. Naturally, there will be more variability in the depictions of deity utilized privately by individuals in family units, as they generally do not answer to broader prosocial forces.

Several considerations support interpreting stelae in Iron Age Israel and Judah as having functioned as divine 'bodies', presencing whichever deities they indexed. ${ }^{13}$ The word מצבה, meaning 'stood up' or 'erected', reflects the upright orientation of the stones, which stand out within the environment, indicating intentionality and agency to viewers. Given its durability, stone was also likely perceived as one of the more suitable materials for hosting the agency of the deceased/divine. Unworked stone may have boasted the additional feature of a more natural state (perhaps the state in which a deity left it), rather than one forced on the stone by human industry. Flat stones placed horizontally before stelae to function as offering tables suggest rituals similar to those performed for the deceased were likely performed for the deities the stelae indexed (Garfinkel, Ganor

much more inexpensive terracotta plaques. The effacement of Egyptian influence meant the similar withdrawal of the wealth and markets it facilitated, so locally produced plaques, statuettes, stelae and cult stands became less expertly and more inexpensively produced. By Iron Age I, the fertility aspects of the divine were depicted primarily through symbols and 'substitute entities' like a tree, a scorpion or a suckling mother animal; see Keel and Uehlinger (1998: 128).

${ }^{13}$ In addition to the well-known stelae at Arad, Iron Age stelae have been found in cult installations and other contexts in Tel-Dan, Hazor, Bethsaida, Lachish, Tirzah, Tel-Rehov, Beth-Shemesh, Tel-Qiri, Timna, Shechem, Khirbet Qeiyafa and in other locations. See further Mettinger (1995: 149-68); Bloch-Smith (2015: 100); Zukerman (2012: 41-3); Herring (2013: 53-63); Garfinkel, Ganor and Hasel (2018: 131-4). 
and Hasel 2018: 131-2). ${ }^{14}$ For instance, two open air sanctuaries at Hazor dating to the eleventh century BCE prominently featured stelae and included cultic assemblages; the stele at Area A was surrounded by three offering tables (Ben-Ami 2006: 123-7). At Khirbet Qeiyafa, three tenth-century BCE cult rooms featuring stelae were discovered. Room J in Building D and Room G in Building C3 each featured large stelae with stone offering tables at their bases and benches adjacent to them (Garfinkel, Ganor and Hasel 2018: 134-46). ${ }^{15}$ The former appears to have been a public cult installation, while the latter was found among a row of houses and may have been private. Similar private installations dating to the end of the second millennium BCE have been found at Lachish and Tel-Qiri (Zukerman 2012; Garfinkel, Ganor and Hasel 2018: 144-5). ${ }^{16}$ A ninth century BCE open air sanctuary is known from Tel REhov that featured a raised platform with two stelae, an offering table, a pottery altar and a large number of animal bones (Mazar 2015: 27-8). The offering of food and the ritual sharing of meals before these stelae suggest the presence and participation of the entities they indexed.

Another consideration is the terminology used in comparative texts to refer to stelae. In addition to the upright and intentional posture of a מצבה, the Ugaritic and Akkadian words for 'stele' (skn and si-ik-ka-num) appear to derive from a verbal root meaning 'to inhabit' (Durand 1985; Dietrich, Loretz, and Mayer 1989; van der Toorn 1997a; Fleming 2000: 82-7; Hundley 2013: 356-8; Yasur-Landau 2016; Scheyhing 2018). This terminology resonates with Jacob's designation of a stele he sets up and anoints with oil as the בית־אלהים ('house of God') in Gen. 28.22. Anointing with oil likely represented a commissioning of sorts (cf. Gen. 35.14-15), although significantly (and perhaps deliberately $)^{17}$ less elaborate than the complex rituals of Mesopotamia and Egypt. ${ }^{18}$ The shortened form, בית־אל, would later become a designation for 'stele' that would be adapted in Greek as $\beta \alpha i ́ \tau v \lambda$ os, 'betyl'. By the seventh century BCE, Assyrian sources identify a West Semitic deity named Bethel who also appears in later Aramaic and Greek texts (Sommer 2009: 28-9). In his first century CE Phoenician History (preserved in Eusebius' Preparation for the Gospel), Philo of Byblos describes betyls as $\lambda$ í $\theta$ or $\tilde{\mu} \mu \psi v \chi 01$, 'enlivened stones' (Baumgarten 1981: 16). The concept of the divine animation of stelae enjoyed wide circulation around ancient Southwest Asia.

The model shrine may have been another means of divine embodiment and presencing in ancient Southwest Asia. These shrines have been discovered at many ancient sites in Israel/Palestine, including Dan, Tel Rekhesh, Tel Rehov, Tirzah, Megiddo, Jerusalem and Khirbet Qeiyafa (Zevit 2001: 328-43; Mazar and Panitz-Cohen 2008; Garfinkel and Mumcuoglu 2015; Mazar 2015: 36-8; Garfinkel, Ganor and Hasel 2018: 146-55). Temples were not as scarce in Iron Age Israel and Judah as previously thought, but the

\footnotetext{
${ }^{14}$ According to Mettinger (1995: 191-2), stelae functioned primarily to facilitate sacrifices and shared communal meals. Note the communal meal mentioned in Exod. 24.11 after the elders of Israel 'saw the God of Israel' (אראו את אלהי ישראל Smith (2008: 58-61) elaborates on the importance of the communal meal to covenant ritual.

${ }^{15} \mathrm{~A}$ recently excavated Judahite temple from Tel Moza features a room near the entrance with five stelae at the base of a bench. See Kisilevitz (2015: 51).

${ }^{16}$ In Zevit (2001: 123) and Hitchcock (2011), these installations are designated 'cult corners'.

${ }^{17}$ Some already suspect certain idiosyncrasies were adopted as identity markers to distinguish Israel and Judah from the societies surrounding them, and this certainly may have been an additional way to distinguish themselves in their relationship to their deity/deities.

${ }^{18}$ Sommer (2009: 49) rhetorically asks, 'Is it possible that, in these passages, anointing transforms the stele and thus functions in a manner comparable to the mis pî ritual in Mesopotamia?' As he notes in a footnote (2009: 207 n.67), several midrashim insist the oil that anointed these stelae came down directly from heaven, which is reminiscent of the insistence at the end of the Mesopotamian ritual that the statue was not made by human hands.
} 
discovery of model shrines in a variety of contexts suggests there was a desire to localize or perhaps mobilize the access to the divine that temples were thought to facilitate. Following patterns found in surrounding cultures, they were usually modelled from clay (sometimes stone), had large openings flanked by pillars, held doors at one time and included space likely intended for the placement of a figurine or some representation of a deity, whether anthropomorphic or otherwise, or iconic or not (Garfinkel, Ganor and Hasel 2018: 146-55). This interpretation is supported by the discovery of a Middle Bronze IIB clay model shrine in Ashkelon that housed a bronze calf figurine covered in silver plating, as well as by carved ivory representations of receding frames around a royal or divine woman's face (Stager 2008; Garfinkel, Ganor and Hasel 2018: 152). The reification of a temple's sacred space may have been a means of (1) facilitating more fully access to divine agency; (2) allowing the image to be carried in processions throughout the community; or (3) 'democratizing' access to temple worship. The use of clay and stone may reflect the perception that both 'natural' substances are efficient or effective means of channelling unseen agency.

The Taanach cult stand, dated to the tenth century всE, likely overlapped in function with model shrines, although it is not prototypical of them (Hestrin 1987; Beck 1994; Keel and Uehlinger 1998: 169-79). The terracotta stand features four vertically arranged friezes that (beginning from the bottom) depict (1) a nude female with outstretched arms touching the ears of lions on either side of her; (2) cherubim-type figures on each side of a gap or empty space; (3) a stylized tree with feeding caprids flanked by lions; and (4) a horse below a sun disk, flanked by outward-facing volutes. ${ }^{19}$ Above the top register is a row of clay circles likely representing roof beams. The four registers may vertically arrange the rooms of the shrine, rather than depict concentric entryways ('recessed doorframes') surrounding the image in the inner sanctuary, as in other model shrines (Garfinkel and Mumcuoglu 2015). If this is the case, the empty space between the cherubim may represent the entrance to the shrine (rather than aniconically signalling YHWH's presence between הכרבים, 'the cherubim', as in Exod. 25.22 and other biblical texts).

Brian Doak (2015: 129) contends that several observations support interpreting the stand as entirely devoted to a goddess. First, the clearest indications of the stand's referent are the bottom and third friezes, which depict a female deity anthropomorphically and as a tree. The other two friezes contain the empty space - likely representing the entrywayand the equid underneath the sun disc. Next, the equid is used predominantly to represent Anat and Astarte, as noted by Izak Cornelius (2008: 40-5) as well as Othmar Keel and Christoph Uehlinger (1998: 160), who also note that Early Iron Age terracotta figures predominantly represent female agents. ${ }^{20}$ The multiple manifestations of the goddess may have been intended to represent the iconography of the different rooms of the temple and her manifestations within them, or to increase the accessibility or compound the potency of her agency. Model shrines were generally too elaborate for widespread private use, but

\footnotetext{
${ }^{19}$ There has been some debate about these representations, and particularly regarding the animal in the upper register. Early interpreters understood it as a bull, perhaps as a result of the interpretation of the stand as Yahwistic in orientation. On the protective role of the naked female and her attendant animals on cult stands, see Darby (2014: 330-8).

${ }^{20}$ Darby (2014: 333) also notes that 'almost every cult stand combines female figurines with zoomorphic images'. The fifty-seven clay figurines and zoomorphic vessels discovered at Tel Rehov further support this observation. Almost half of the figures were anthropomorphic, and almost all were female, while nearly a third of the twentynine zoomorphic figurines and vessels depicted equids. See Mazar (2015: 38-9).
} 
their use in local cult installations could increase access to the agency of the (primarily female) deities they indexed for those living nearby.

\section{Forming divine bodies in the Hebrew Bible}

The authors and editors of the Hebrew Bible usually downplayed the significance of presencing media, especially to the degree that the media in question overlapped with the practices of surrounding societies, and particularly those that socioculturally competed directly with Israel and Judah. That does not mean that the biblical writers unilaterally rejected the efficacy or appropriateness of presencing media; rather, it means they curated a very specific set of what were considered sanctioned means of forming divine bodies. In what follows, I will outline a trajectory towards the rhetorical compartmentalization of the deity from the loci of their agency. In other words, whereas Israel and Judah's earliest cultic objects functioned in many ways as divine 'bodies', as time progressed and cultic authority became more and more centralized, those authorities began to assert the deity's primary location elsewhere, even as they asserted the deity's ability to be presenced to some degree through accessible material media. We might frame this development as a process not only of subordinating and demoting presencing media but also of 'democratizing' access to that media.

Perhaps the most iconic of sanctioned icons in the Hebrew Bible is the ark of the covenant. In form and function, the ark closely parallels divine images from broader ancient Southwest Asia. Some biblical texts describe it as a container for the law, which resonates with the Mesopotamian convention of presenting treaties to divine images for their approval and enforcement. David Aaron (2001: 172-5) has highlighted a unique construction in Exod. 25.16, 21 related to the ark's relationship to the testimony (העדת). Rather than employing the conventional בארון, 'in the ark' (Deut. 10.2, 5; 1 Kgs 8.9), these passages command Moses to 'give' (נתן) (נאר הארן the testimony 'to the ark', which complements the practice of placing treaties before the divine image. The language is just fuzzy enough to be reinterpreted in harmony with the Deuteronomi(sti)c constructions, especially if much of the audience were unfamiliar with the technical sense of the phrase, and so it may have escaped excising editorial hands accustomed to removing other language that more explicitly framed the ark as a Yahwistic cult image.

As a container, the ark is also analogous to the portable model shrine. The storage of these shrines in cult rooms parallels the ark's storage in the cella of the tabernacle/ temple, and their portability likely facilitated their use in processions, including before military forces, which would match the function of the ark in texts such as Josh. 6.411 and 1 Sam. 14.18. In ancient Egypt, model shrines often took the form of boats that carried the divine image within a canopied throne. Some were even flanked by winged entities reminiscent of cherubim (Noegel 2015). The more the divine image was embedded within material relationships that evoked divinity and the themes and imagery of ritual, the more strongly the image could be perceived to presence deity. These variations on the same theme were meant for the transportation of a small-scale divine image within an object that could reify sacred space. If the image was to permanently remain in the cella or cult room, the secondary reification of that sacred space would have been redundant. There is no need for a small-scale reproduction of sacred space that remains embedded within sacred space - the model shrine was intended to render the divine image portable. 
The biblical texts nowhere explicitly mention an anthropomorphic image associated with the ark, although its conceptualizations as a throne and even as a footstool evoke concepts of an enthroned person and fits with Southwest Asian conventions regarding divine images. A wall relief from the Nimrud palace of Tiglath-pileser III (745-727 BCE) depicts a procession of deities taken from a conquered cult precinct (BM 118931). Three of the deities are unambiguously anthropomorphic (with two sitting upon thrones), but one depicts what appears to be a box sitting on a throne, with what may be a small hand, grasping a ring, protruding from the front of the box. This may depict a model shrine carrying a small divine image. An anthropomorphic image is not necessarily required, however, for a throne or footstool to function as presencing media. Offerings to thrones and other items of cultic furniture are known from Akkadian ritual instruction texts. One such text from the neo-Babylonian period includes the directive that twelve loaves of bread are to be prepared for the 'Throne of Anu' (Porter 2009: 155-6). The standard and the footstool of Shamash also had mouth-opening rituals performed for them at Mari (Walker and Dick 2001: 12).

At the same time, there is some biblical evidence that non-anthropomorphic statuary presenced the deity within the ark. It is not an enormous conceptual leap to link the tablets of the law with cultic stelae, particularly in the light of the command to write the words of the law upon cultic stelae in Deut. 27.1-10 and Josh. 8.32, 34-35 (Stavrakopoulou 2013). In Exodus 32 (P), the tablets of the law are also rhetorically cast as the authorized alternative to the golden calf - they are a divinely sanctioned medium for divine presencing. Both types of entity function as a cultic image in different ways. For instance, the golden calf and the stone tablets make use of materials traditionally associated with the divine. The divine production of the text of the tablets is emphasized in Exod. 32.16, while Aaron asserts in v. 24 that the golden calf just 'came out' of the fire, as if it were not the work of human production. A critical distinction is Aaron's assertion that the calf actually presences the locus of the deity's identity: 'These are your deities, O Israel!' (Exod. 32.4). This stands in contrast to the treatment of the tablets as a secondary divine agent.

If figurines such as the small bronze bull discovered near Dothan - likely associated with a model shrine - and the miniature anthropomorphic statue that may be jutting its hand out from the enthroned box in the Tiglath-pileser III relief are representative of the kind of media used in conjunction with model shrines, those media could have been miniature versions of full-scale divine images used in larger sites. The most explicit examples we have of full-scale divine icons used in an Israelite/Judahite cultic site are the stelae that were located in the cella of the Arad temple. We have already seen that such stelae were ubiquitous across the regions inhabited by ancient Israel and Judah, and the biblical texts are replete with references to cultic stelae, so they are very likely to have been broadly representative of the type of divine image employed in Israel and Judah. Tablets would very easily function as miniature stelae, and here the presencing function of cultic objects and of text converge (Watts 2016). The significance of this will be discussed further below, but given the ubiquity of stelae in and around Israel and Judah, and the general paucity of anthropomorphic statuary, the ark may have functioned at some point as a portable model shrine housing one or more stelae that presenced the deity or the deity and a consort. By the time of the work of the Deuteronomist, this function seems to have given way to other conceptualizations that still served to presence the deity without appealing to more conventional imagery associated with cultic objects. 
Some of the clearest biblical indicators that the ark functioned to reify the presence of YHWH is the use of the phrase לפני יהוה, 'before YHWH', in connection with the location of the ark. In the Hebrew Bible, this is a technical construction that reflects appearance before a cultic object and/or within a cultic installation such as the Jerusalem temple. For example, in 2 Sam. 6.5, 14-16, David and all the house of Israel were משחקים לפני יהוה, 'dancing before YHWH', while they travelled with the ark towards Jerusalem. In a slight twist on that formula, Josh. 7.6 describes Joshua tearing his clothes and falling down on his face לפני ארון יהוה, 'before the ark of YHWH'. The Septuagint omits 'ark' (as it also does in Josh. 6.13). 2 Samuel 6.2 even states that the ark is נקרא שם שם יהוה צבאות, 'called by the name, the name of YHWH of hosts'. Deuteronomy 10.8 describes the tribe of Levi as being set apart to לשאת את־ארון ברית־יהוה לעמד לפני יהוה לשרתו ולברך בשמו עד היום הזי ל, "carry the ark of the covenant of YHWH, to stand before YHWH to minister to him, and to bless in his name, until this day'. As Anne Knafl (2014: 131) explains, 'By carrying the ark, the Levites stand before YHWH and there minister to him.' Like the fire out of which YHWH spoke to Israel in Deut. 4. 12, 15, the ark does not necessarily reify the single and sole locus of the deity's very identity, but it does function as an extension of the deity's agency, thereby intuitively presencing the deity.

The ark likely functioned as a divine 'body' throughout its existence, even if its specific conceptualization as such was manipulated in the service of structuring power. ${ }^{21}$ The ark narrative in 1 Samuel 4-6 makes use of the abandonment motif to assert the severability of the deity's agency from the ark and to account for the loss of the ark to the Philistines (pinning the blame on the wickedness of the sons of Eli), but (pace Sommer 2009: 1017) this does not remotely approximate the outright rejection of any and all presencing facilities on the part of the ark. Instead, the data support a more nuanced renegotiation of the deity's relationship to the temple and its cultic accoutrements that compartmentalized the loci of both the deity's identity and the deity's agency. The ark remained a medium for, or extension of, YHWH's power and agency, even as it was decoupled or distanced from the main locus of the deity's identity. Deuteronomy 4 even more explicitly lays out this rhetorical agenda in explaining that although YHWH's voice was heard from the fire, there was no form seen because YHWH was located in the heavens. While still in some sense one of YHWH's 'bodies', the ark and the fire are subordinated and made secondary vehicles of YHWH's agency.

By the time these texts were written and in circulation, however, the ark was no longer extant. The weakening of the isometry of YHWH and the ark served several rhetorical functions vis-à-vis that absence. By presenting the (now absent) ark as a

\footnotetext{
${ }^{21}$ In his 2009 monograph on divine bodies, Sommer argues that the presentation of the ark in 1 Samuel 4-6, and particularly its failure to secure victory for Israel at Ebenezer, demonstrates a rejection of the 'fluidity' model he constructs to account for the capacity for different material media to presence the deity (2009: 99-107). Rather than flatly deny the presencing power of the ark, however, it is more likely that the ark's apparent failure in battle is intended to highlight YHWH's abandonment of the ark in light of the wickedness of Eli's sons. Sommer acknowledges this rhetorical option in his discussion of divine fluidity in Mesopotamia, but it is not addressed discussing this narrative: 'The șalmu ... was itself a god, assimilated into the heavenly god yet physically a distinct thing that could lose its divine status at any moment, should the deity choose to abandon it' (2009: 23). Given the fact that communities in Mesopotamia could acknowledge the abandonment of the salmu without rejecting the entire concept of divine fluidity (as Sommer himself discusses at 2009: 21-2), there is little reason to accept that the ark's failure to secure a victory indicates a rejection of the very ideology present in the latter half of the narrative (and for which Sommer is at pains to account). On the abandonment motif, see Cogan (1974: 9-21); Kutsko (2000: 104-23); Block (2000: 114-26); Holloway (2002: 54-5). The destruction of the temple at the hands of the Babylonians is also framed in terms of divine abandonment in Ezekiel.
} 
uniquely situated medium for the deity's agency, the authors/editors of Deuteronomy and the Deuteronomistic literature limited the other available objects of potential worship, perhaps to mitigate the risk of other divine images replacing the ark. YHWH's abandonment of the ark was also a more favourable outcome than the deity's wilful selfexile to the sacred precinct of whichever empire absconded with it; it allowed for the assertion of YHWH's remaining with worshippers. The authoritative knowledge these rationalizations helped to codify not only served immediate rhetorical needs but also created new conceptual relationships that would have to be renegotiated as the corpus of Israel and Judah's authoritative texts began to take shape. ${ }^{22}$

One of the more significant of these conceptual relationships related to the presencing of the deity in the absence of the ark. Jeremiah 3.16-17 dismisses the significance of the ark and prophetically expands the purview of the Jerusalem temple beyond its physical existence to the point that the city itself is recast in the role of the ark as the throne of YHWH. Ezekiel 1 and 10 do not mention the ark, but similarly shatter the confines of the physical temple, envisioning a portable cherubim throne on which the deity travelled. Isaiah 66.1 further expands the rhetoric about the deity's purview, casting the heavens as the deity's throne and the earth as the footstool. While this rhetoric allowed authors to rationalize the loss of the Jerusalem temple while exalting the deity further, there remained a need to be able to focus the ritual/cultic attention of the people and still provide for the presencing of the deity among the people, particularly as the deity became increasingly transcendent. What better way to do this than to replace the ark as the loci of immanent divine presence with the very contents it was said to house: the Torah and the divine name that the Torah bore?

This role for the Torah (and more specifically the discrete lists of the deity's apodictic and casuistic laws) represents a significant innovation, within Judah, on the use of text to presence deity. This did not originate here, of course. According to Nathaniel Levtow (2012: 311), as far back as the third millennium BCE, 'text production was a ritualized activity that embodied divine and human subjects in textual form'. Deuteronomy 27.110 helpfully illustrates the way this innovation might have been implemented in ancient Israel/Judah. This text describes instructions given by Moses and the elders of Israel to erect (קום) large stones, plaster them and write upon them the words of the Torah (likely an early law code later incorporated into Deuteronomy). They are then to construct an altar of unhewn stones, offer burnt offerings to YHWH and share a communal meal while rejoicing לפני יהוה אלהיך, 'before YHWH, your deity'. According to v. 9, this ritual process (which makes no mention of an oral recitation or a requirement to read the text) 2 $^{23}$ facilitates their becoming the 'people of YHWH' (עם יהוה). The features of this ritual act combine wider cultural conventions of sealing treaties with traditional acts of communal worship before divine images. The use of the לפני יהוה formula indicates the stelae's presencing of the deity's agency, which was most likely reified through the divinely given words of the covenant that were written on the stones. These words would have included the deity's first-person speech and numerous iterations of the divine name. Writing the text on the stones may thus be thought of as sacralizing or commissioning the object,

\footnotetext{
${ }^{22}$ For a fascinating discussion of how the ubiquity of abducted divine images may have undermined neo-Assyria's traditional conceptualization of the relationship of cult statues to their deities, see Richardson (2012).

${ }^{23}$ It is not until Deut. 31.11 that the Sinai event is re-enacted with the reading of the entire law. See also Josh. 8.30-35, which has Joshua writing the law on the stones (apparently of the altar) and then reciting every last word before the Israelites. Cf. Schaper (2007).
} 
endowing it with the divine agency previously facilitated by anointing, incantations and/ or other ritual. As noted by Francesca Stavrakopoulou (2013: 228), 'The narrator appears less concerned with the specifics of the "message" of Torah than with the performance of writing and other rituals ... it is the material manifestation of Torah that is of central concern in this passage'.

This biblical passage does not polemicize or prohibit the material presencing of deity so much as constrain the accessible and reproducible media for that presencing. By requiring the imposition of the text of the covenant upon the generic stelae, the Deuteronomist did not invalidate cultic objects but restricted the production of and access to sanctioned cultic objects to those who were literate and/or could access the text of the Torah. ${ }^{24}$ The only such groups in this early phase of the Torah's existence were the elite scribal classes who produced that text under the purview of their cultic authorities. ${ }^{25}$

Also significant are the prescriptions outlined in Exod. 13.9, 16 and Deut. 6.6-9; 11.18-21, which are widely understood to be Achaemenid period compositions. These passages command the people to recite the words of the covenant to their children, to discuss them at home and abroad, to bind them as a sign upon their hands and as 'emblems' between their eyes ${ }^{26}$ and to write them on their doorposts and gates. Here the text of the Torah is integrated into practices associated with inscribed amulets. The words of the law themselves have become salient, but still only insofar as they are both oralized and materially present (Schaper 2007: 14-16). ${ }^{27}$ Stelae were marginalized within the scribal community by this time, but the words themselves, independent of their media, were not yet authoritative - the need for and the rhetorical utility of the material mediation of the law remained (cf. Polaski 2007).

There is a sense in which the promiscuous presencing of the words of the deity democratized access that had frequently been restricted in earlier periods, perhaps for some even privatizing the temple/cult site experience. By reframing that presence in terms of the Torah instead of the deity, however, the goal also (or rather) appears to have been to extend the centralized cult's reach out into the diaspora, transferring the people's socio-material focus away from YHWH and onto the scribal class' institutional

\footnotetext{
${ }^{24}$ I use 'and/or' to reflect the reality that even those who could not read could recognize writing or even identify some words - especially those widely understood to be powerful. A person who could not read could conceivably reproduce a crude version of the Torah by copying the shapes, but they would still need some kind of access to it. Sanders (2019) finds that the inclusion of memorial inscriptions on mortuary stelae (and specifically inscriptions that presenced the dead and demanded their feeding) was an innovation of the early Iron Age in the West Semitic world.

${ }^{25}$ Note Stavrakopoulou (2013: 234): 'In robust materialist perspective, socio-religious and economic power is thus held by those who literally and literarily hold Torah - to the exclusion of those who do not and cannot participate in the textuality of the covenant.' Another text, Josh. 24.25-27, reflects a similar renegotiation of the relationship of text and cult but employs the motifs differently (cf. Stavrakopoulou 2013: 229). There the words of the deity are materially manifested on a scroll rather than a stele, but that scroll is immediately backgrounded as a stele is erected to monitor the people's commitment to the covenant into which they have ritually entered. Again, pre-existing conventions of divine presencing are adopted to this textualization of the deity's words, even as those conventions are renegotiated to fit the new paradigm. The stone does not so much presence the deity as function as an independent agent, having heard the words of the deity and having witnessed the people's entry into the covenant. Functionally, the stone acts as a 'witness' by reminding viewers of the covenant, but its presence alone is enough to reify a sense of unseen monitoring, whether or not it was identified with a specific unseen agent.

${ }^{26} \mathrm{I}$ use 'emblems' here to gloss טוטפת. The word is unattested in the Hebrew Bible outside of these verses but may have indicated some kind of adornment for the head. See further Tigay (1982); Cohn (2008: 33-53).

${ }^{27}$ The word traditionally translated 'meditate' in Josh. 1.8 (הגהת) means to read in an undertone or to mutter, not to silently ponder.
} 
purview: the Torah. As with the passages discussed above, the words of the text itself were not the primary focus; rather, that focus was the material carrier of the text. At the beginning of this trajectory towards the textualization of divine presencing, the text either accompanied or was overlaid upon an existing means of materially presencing a deity, but the larger and more conspicuous of those means (such as stelae) were largely phased out by the Achaemenid period. This would leave smaller amulets and other adornments that had not fallen victim to priestly proscription, such as seals or the Ketef Hinnom amulets, to become the sacralized material bearers of the Torah and, just as significantly (if not more so), the divine name (cf. Schmid 2012).

The first-person voice of much of the Torah introduces an additional dynamic associated with divine presencing. Biblical traditions suggest the 'first' iterations of the Torah were written in the first person - even by YHWH's own finger - reflecting the deity's own voice and intuitively conjuring for the reader some concept of the speaker. This was likely in imitation of wider, developing conventions regarding monumental inscriptions (Hogue 2019c). Across multiple publications, Seth Sanders has promulgated the theory that monumental inscriptions not only served to mark property and memorialize sociomaterially significant space, but also - by the time first-person narrative began to appear on alphabetic memorial inscriptions - to 'ventriloquize' the author (see especially Sanders 2008, 2010). While Sanders focuses on the Mesha Stele as one of the earliest examples, ${ }^{28}$ a helpful example for the present discussion is the Katumuwa inscription, whose owner declares in the first line:

1 'nk.ktmw.'bd.pnmw.zy.qnt.ly.nșb.b.

2 hyy ....

1 I am Katumuwa, servant of Panamuwa, who created ${ }^{29}$ this stele for myself during 2 my life.

This first-person speech is intended to presence the agency of the deceased. According to Timothy Hogue (2019a: 200), 'It was the materialization of Katumuwa's presence and agency so that he might interact with future users of the monument.' In the absence of a son to erect a mortuary stele for him, Absalom is said in 2 Sam. 18.18 to have erected his own stele, which could well evoke an inscribed monument written in first-person speech. Seth Sanders (2012: 35) distinguishes first-person mortuary inscriptions from earlier iterations: 'The new inscriptions and monuments actually speak on behalf of the dead and make demands for themselves. They are designed to produce the presence of the dead and demand their feeding' (cf. Radner 2005: 114-55).

אנכי יהוה אלהיך :Compare such first-person speech to the opening line of the Decalogue אשר הוצאתיך מארץ מבית עבדים , 'I am YHWH, your deity, who brought you up from the land of Egypt, from the house of slavery' (Exod. 20.2). Whether read or heard, the agency

\footnotetext{
${ }^{28}$ See Sanders (2010: 114):

The stela of Mesha is the first known alphabetic inscription to address an audience in the first-person voice of the king. It presents a man who claims, in Moabite, to be the king of Moab. The shift in participants from earlier alphabetic royal inscriptions is decisive. The inscription now designates itself by the speaker, not the object. No longer '(this is) the stela which Mesha set up' but 'I am Mesha, son of Kemoashyat, King of Moab, the Dibonite'. The inscription presents royal power by making the king present in language, ventriloquizing Mesha as if he were standing in front of us.
}

${ }^{29}$ I have followed Hogue (2019a) in understanding the verb qny to reflect creation in certain contexts. Hogue bases his argument on the conventions of Luwian monumental inscriptions. 
of the deity is essentially made present by the first-person voice of the text. As Timothy Hogue explains,

The result is an imagined encounter with the projected speaker implied by the pronoun 'I'. This process of deictic projection thus conjures a speaker - reembodying them in the imagination of the audience. The opening line of the Decalogue - 'I am Yahweh' is not a prosaic statement nor even a mere adaptation of royal monumental rhetoric. This statement actually produces the presence of Yahweh in the minds of the readers and hearers of the text. It is a theophany condensed into a formula. (Hogue 2019b: 11)

As the very first words of the law given by YHWH, these would have been the first words written, according to Exod. 31.18, on the tablets of stone given to Moses. This text also states the words were written with the deity's own finger, distinguishing the tablets from the golden calf, which in this particular version of the tradition is an unauthorized cult image produced by human hands rather than by a deity (cf. Exod. 32.15-16; Deut. 9.821). ${ }^{30}$ In this way, the tablets of the Torah evince significant overlap with more traditional media for divine presencing. Humanity's role in the production of the tablets is also denied through the narrative which asserts their heavenly origins, in line with the authorized cult statues of surrounding cultures (cf. Parmenter 2009). As miniature stelae inscribed with the divine name and the words of the Torah, the tablets are functionally identical to the cultic stelae of Deuteronomy 27 and able to facilitate worship 'before YHWH'. The original objects (the narratives alternate between clay tablets or small stelae) were thus created by the deity, contained words written by the deity and spoke in the first person as the deity, combining multiple conventions of the production of divine images with those of monumental inscriptions to indicate the Torah's capacity to presence the deity. The later commandments to write the Torah (in whatever iteration) upon or before stelae reflect variations on this same theme: the agency of the deity is appropriately made present in the reading, hearing or even just the presence of the Torah. ${ }^{31}$

In later religious practice, the treatment of the divine name and texts bearing the divine name further attest to its conceptualization as a species of presencing media. The Jerusalem temple had been rebuilt in the late sixth century BCE, but the Torah was now presented as an equally powerful locus of divine presencing, and legal authorities were in no hurry to relinquish the access to, and influence over, divine agency their stewardship of the texts afforded them. Throughout the Second Temple period, Yahwistic theophoric elements were appearing less frequently in personal names, likely out of reverence for, and avoidance of saying aloud, the Tetragrammaton. ${ }^{32}$ In a sense, avoiding writing or pronouncing the divine name in common circumstances evinced a desire not to invoke the deity's presence in 'profane' contexts. ${ }^{33}$

\footnotetext{
${ }^{30}$ In Exod. 32.19, Moses goes on to shatter these tablets, but in 34.1, YHWH commands Moses to carve two new tablets, on which YHWH will again write the words of the Torah. According to 34.28, however, Moses writes on the tablets.

${ }^{31}$ See Watts (2016: 21): 'the Pentateuch was shaped to lay the basis for Torah scrolls to replace the ark of the covenant as the iconic focus of Israel's worship'. Cf. Schniedewind (2009: 78-9).

${ }^{32}$ See Schniedewind (2009: 75): 'By the end of the Second Temple period these names will have disappeared completely, corresponding to the increasing reverence for the Tetragrammaton that is evident in the late Second Temple period.'

${ }^{33}$ This reverence for the texts bearing the divine name is demonstrated by practical observances associated with their transcription. For example, nearly thirty of the Dead Sea Scrolls manuscripts were written in the square Aramaic script, but represented the Tetragrammaton in a palaeo-Hebrew script. In many cases, scribes left gaps in the transcription where the divine name was to appear, and more senior scribes would come through later and
} 
By the time of the destruction of the Second Temple in $70 \mathrm{CE}$, an authoritative corpus of literature was taking firmer shape, and Jewish authorities were once again wrestling with accessing divine agency through text and in the absence of temple literature. The form and function of the Torah and other authoritative texts became a focal point of early rabbinic literature, at which point standardized guidance began to come into clearer focus. The oft-quoted guiding principle from this period was the final clause from the opening passage of the Mishnaic tractate Pirkei Avot, which reflects the conceptualization of the Torah as reifying sacred space: 'make a fence around the Torah'. In the Mishnah's Yadayim 4.5, biblical texts are not said to 'defile the hands' unless and until 'they are written in the Assyrian script, on parchment, and in ink'. ${ }^{34}$ The Talmud lays out further prescriptions regarding the preparation of the parchment from appropriate animal skins, the production of the scrolls themselves (codices were not adequate) ${ }^{35}$ and their handling. Marianne Schleicher (2010: 14) describes these conventions as 'projecting a status of holy axis mundi onto the Torah scroll.... In line with this conception, the Torah is even referred to as God's temple (mikdashyah) in medieval writings.' The sixteenth-century legal code Shulkhan Arukh even requires uttering the following statement out loud before beginning to write a Torah scroll: 'I have the intent to write the holy name' (Shulkhan Arukh, 'Yoreh Deah', 276). For Schleicher (2010: 15), this indicates that 'every Jew writing a scroll had to remind himself of its numinosity and thereby contribute to the maintenance of the status of the Torah as a holy artifact'. These practices have clear conceptual parallels to the preparation and installation of cultic statues (cf. van der Toorn 1997b).

\section{Conclusion}

In ancient Israel and Judah, divine bodies were conceptualized as partible and permeable. As a result, the loci of divine agency and identity were perceived as communicable via a variety of material media. The means of their production for immediate access by human agents do not represent significant departures from those of the larger empires that surrounded ancient Israel and Judah. Rather, they represent incremental innovations on shared conventions that likely came in reaction and response to rhetorical exigencies within specific social and cognitive ecologies. The much smaller and more limited markets of Israel and Judah did not require or particularly allow for elaborate rituals and expensive anthropomorphic statuary, but on a smaller and simpler scale, YHWH and other deities were still made accessible for authorities and devotees through stelae and other cultic objects that could be commissioned through sanctioned means in order to reify the presence of the deities and function as a localized 'body'.

A significantly more restricted and idiosyncratic view of divine embodiment remained after the projection of these socio-material conventions through the reflective filters of the authors and editors of the Hebrew Bible. Fewer instantiations of divine embodiment were permitted to be represented in a favourable light. The primary concerns, however,

insert the divine name in the palaeo-Hebrew script. That this was not just a stylistic consideration, but evidence of special treatment, is indicated by one manuscript, $11 \mathrm{QPs}^{\mathrm{a}}$, in which twenty-eight words were erased from the transcription, except for the Tetragrammaton. In another eight manuscripts, the divine name was substituted with four dots, sometimes called the 'Tetrapuncta'. See Tov (2004); Lichtenberger (2018); cf. Parry (1996).

${ }^{34}$ For a brief discussion of the reception of translations of the Hebrew Bible as holy writings, see Smelik (1999). See also the contributions in Law and Salvesen (2012).

${ }^{35}$ For the development of the codex as diagnostic of Christian literature, see Nongbri (2018: 21-46). 
appear to have been related to the relationship of those socio-material conventions to surrounding social groups and to the vicissitudes of curating socio-material media, and not to the practice of divine embodiment in and of itself. As a result, some notable examples not only remained but became central to the changing conceptualization of YHWH's relationship with, and presence among, worshippers. The loss of the ark of the covenant necessitated a new means of divine presencing that could escape the risks inherent in a discrete cultic object that might be destroyed, captured or inappropriately worshipped. The text of the Torah, empowered by the material presence of the divine name, became YHWH's new 'body' and the medium for the deity's presence among people.

\section{References}

Aaron, D. H. (2001), Biblical Ambiguities: Metaphor, Semantics and Divine Imagery, Leiden: Brill.

Asher-Greve, J. M. (1997), 'The Essential Body: Mesopotamian Conceptions of the Gendered Body', Gender \& History 9 (3): 432-61.

Barrett, J. L. (2011), Cognitive Science, Religion, and Theology: From Human Minds to Divine Minds, West Conshohocken, PA: Templeton Press.

Baumgarten, A. I. (1981), The Phoenician History of Philo of Byblos, Leiden: Brill.

Beal, R. H. (2002), 'Dividing A God', in P. Mirecki and M. Meyer (eds), Magic and Ritual in the Ancient World, 197-208, Leiden: Brill.

Beck, P. (1994), 'The Cult Stands from Taanach: Aspects of the Iconographic Tradition of Early Iron Age Cult Objects in Palestine', in I. Finkelstein and N. Na'aman (eds), From Nomadism to Monarchy: Archaeological and Historical Aspects of Early Israel, 352-81, Washington: Biblical Archaeology Society.

Beckman, G. (2010), 'Temple Building among the Hittites', in M. J. Boda and J. Novotny (eds), From the Foundations to the Crenellations: Essays on Temple Building in the Ancient Near East and Hebrew Bible, 71-89, Münster: Ugarit-Verlag.

Ben-Ami, D. (2006), 'Early Iron Age Cult Places - New Evidence from Tel Hazor', Tel Aviv 33 (2): 123-7.

Bennett, G., and K. M. Bennett (2000), 'The Presence of the Dead: An Empirical Study', Mortality 5 (2): $139-57$.

Benzel, K. (2015), “'What Goes in Is What Comes Out” - But What Was Already There? Divine Materials and Materiality in Ancient Mesopotamia', in B. Pongratz-Leisten and K. Sonik (eds), The Materiality of Divine Agency, 89-118, Berlin: De Gruyter.

Berendt, E. A., and K. Tanita (2011), 'The "Heart" of Things: A Conceptual Metaphoric Analysis of Heart and Related Body Parts in Thai, Japanese and English', Intercultural Communication Studies 20 (1): 65-78.

Bering, J. M. (2002), 'Intuitive Conceptions of Dead Agents' Minds: The Natural Foundations of Afterlife Beliefs as Phenomenological Boundary', Journal of Cognition and Culture 2 (4): 263-308.

Bering, J. M. (2006), 'The Folk Psychology of Souls', Behavioral and Brain Sciences 29: 453-98. Bering, J. M., K. McLeod and T. K. Shackelford (2005), 'Reasoning about Dead Agents Reveals Possible Adaptive Trends', Human Nature 16 (4): 360-81.

Bloch-Smith, E. (1992), 'The Cult of the Dead in Judah: Interpreting the Material Remains', Journal of Biblical Literature 111 (2): 213-24. 
Bloch-Smith, E. (2015), 'Massebot Standing for Yhwh: The Fall of a Yhwistic Cult Symbol', in J. J. Collins, T. M. Lemos and S. M. Olyan (eds), Worship, Women, and War: Essays in Honor of Susan Niditch, 106-10, Providence, RI: Brown Judaic Studies.

Block, D. I. (2000), The Gods of the Nations: Studies in Ancient Near Eastern Theology, 2nd edn, Grand Rapids, MI: Baker Academic.

Boden, P. J. (1998), 'The Mesopotamian Washing of the Mouth (mis pî) Ritual', PhD thesis, Johns Hopkins University.

Chudek, M., R. A. McNamara, S. Birch, P. Bloom and J. Henrich (2017), 'Do Minds Switch Bodies? Dualist Interpretations across Ages and Societies', Religion, Brain \& Behavior 8 (4): 354-68.

Cogan, M. (1974), Imperialism and Religion: Assyria, Judah and Israel in the Eighth and Seventh Centuries BCE, Missoula, MT: Scholars Press.

Cohen, E. (2008), 'What Is Spirit Possession? Defining, Comparing, and Explaining Two Possession Forms', Ethnos 73 (1): 101-26.

Cohen, E., and J. L. Barrett (2008), 'When Minds Migrate: Conceptualizing Spirit Possession', Journal of Cognition and Culture 8 (1): 23-48.

Cohn, Y. E. (2008), Tangled Up in Text: Tefillin and the Ancient World, BJS 351, Providence, RI: Brown University.

Craffert, P. F. (2015), 'When Is an Out-of-Body Experience (Not) an Out-of-Body Experience? Reflections about Out-of-Body Phenomena in Neuroscientific Research', Journal of Cognition and Culture 15 (1-2): 13-31.

Darby, E. (2014), Interpreting Judean Pillar Figurines: Gender and Empire in Judean Apotropaic Ritual, Tübingen: Mohr Siebeck.

Dietrich, M., O. Loretz and W. Mayer (1989), 'Sikkanum "Betyle"', Ugaritische Forschung 2 (1): 133-9.

Doak, B. R. (2015), Phoenician Aniconism in Its Mediterranean and Ancient Near Eastern Contexts, Atlanta, GA: Society of Biblical Literature.

Donner, H., and W. Röllig, eds (2002), Kanaanäische und aramäische Inschriften, 5th edn, Weisbaden: Harrassowitz Verlag.

Durand, J. (1985), 'Le culte des bétyles en Syrie', in J. Durand and R. Kupper (eds), Miscellenea Babylonica: Mélanges offerts à Maurice Birot, 79-84, Paris: Éditions Recherche sur les civilisations.

Earl, J. (2015), 'Dad bikes 1,400 miles to hear deceased daughter's heartbeat on Father's Day', CBS News, 21 June. Available online https://www.cbsnews.com/news/dad-bikes-1400-milesto-hear-deceased-daughters-heartbeat-on-fathers-day/ (accessed 8 May 2020).

Evans, J. St. B. T., and K. Frankish, eds (2009), In Two Minds: Dual Processes and Beyond, Oxford: Oxford University Press.

Fleming, D. E. (2000), Time at Emar: The Cultic Calendar and the Rituals from the Diviner's Archive, Winona Lake, IN: Eisenbrauns.

Garfinkel, Y., and M. Mumcuoglu (2015), 'A Shrine Model from Tel Rekhesh', Strata: Bulletin of the Anglo-Israel Archaeological Society 33: 77-87.

Garfinkel, Y., S. Ganor and M. G. Hasel (2018), In the Footsteps of King David: Revelations from an Ancient Biblical City, New York: Thames \& Hudson.

Hallam, E., and J. Hockey (2001), Death, Memory and Material Culture, Oxford: Berg.

Hamori, E. J. (2008), 'When Gods Were Men': The Embodied God in Biblical and Near Eastern Literature, Berlin: De Gruyter.

Herring, S. L. (2013), Divine Substitution: Humanity as the Manifestation of Deity in the Hebrew Bible and the Ancient Near East, Göttingen: Vandenhoeck \& Ruprecht. 
Herrmann, V. R., and J. D. Schloen, eds (2014), In Remembrance of Me: Feasting with the Dead in the Ancient Middle East, Chicago, IL: University of Chicago Press.

Hestrin, R. (1987), 'The Cult Stand from Ta 'anach and Its Religious Background', in E. Lipiński (ed.), Studia Phoenicia V: Phoenicia and the East Mediterranean in the First Millennium BC, 61-77, Leuven: Peeters.

Hitchcock, L. A. (2011), 'Cult Corners in the Aegean and the Levant', in A. Yasur-Landau, J. R. Ebeling and L. B. Mazow (eds), Household Archaeology in Ancient Israel and Beyond, 321-45, Leiden: Brill.

Hogue, T. (2019a), 'Abracadabra, or "I Create as I Speak": A Reanalysis of the First Verb in the Katumuwa Inscription in Light of Northwest Semitic and Hieroglyphic Luwian Parallels', Bulletin of the American Schools of Oriental Research 381: 193-202.

Hogue, T. (2019b), 'Image, Text, and Ritual: The Decalogue and the Three Reembodiments of God'. Paper presented at the Annual Meeting of the Society of Biblical Literature. San Diego, CA, 26 November 2019.

Hogue, T. (2019c), 'The Monumentality of the Sinaitic Decalogue: Reading Exodus 20 in Light of Northwest Semitic Monument-Making Practices', Journal of Biblical Literature 138 (1): 79-99.

Holloway, S. W. (2002), Aššur is King! Aššur is King! Religion in the Exercise of Power in the NeoAssyrian Empire, Leiden: Brill.

Hundley, M. B. (2013), Gods in Dwellings: Temples and Divine Presence in the Ancient Near East, Atlanta, GA: Society of Biblical Literature.

Hurowitz, V. A. (2006), 'What Goes in Is What Comes Out: Materials for Creating Cult Statues', in G. Beckman and T. J. Lewis (eds), Text, Artifact, and Image: Revealing Ancient Israelite Religion, 3-23, Providence, RI: Brown Judaic Studies.

Järnefelt, E., C. F. Canfield and D. Kelemen (2015), 'The Divided Mind of a Disbeliever: Intuitive Beliefs about Nature as Purposefully Created Among Different Groups of Non-Religious Adults', Cognition 140 (1): 72-88.

Keel, O., and C. Uehlinger (1998), Gods, Goddesses, and Images of God in Ancient Israel, trans. T. H. Trapp, Edinburgh: T\&T Clark.

Keen, C., C. Murray and S. Payne (2013), 'Sensing the Presence of the Deceased: A Narrative Review', Mental Health, Religion \& Culture 16 (4): 384-402.

Kisilevitz, S. (2015), 'The Iron IIA Judahite Temple at Tel Mozaa', Tel Aviv 42: 147-64.

Knafl, A. K. (2014), Forming God: Divine Anthropomorphism in the Pentateuch, Winona Lake, IN: Eisenbrauns.

Kutsko, J. F. (2000), Between Heaven and Earth: Divine Presence and Absence in the Book of Ezekiel, Winona Lake, IN: Eisenbrauns.

Law, T. M., and A. Salvesen, eds (2012), Greek Scripture and the Rabbis, Leuven: Peeters.

Levtow, N. B. (2012), 'Text Destruction and Iconoclasm in the Hebrew Bible and the Ancient Near East', in N. N. May (ed.), Iconoclasm and Text Destruction in the Ancient Near East and Beyond, 311-62, Chicago, IL: Oriental Institute of the University of Chicago.

Lichtenberger, H. (2018), 'The Divine Name in the Dead Sea Scrolls and in New Testament Writings', in R. A. Clements, M. Kister and M. Segal (eds), The Religious Worldviews Reflected in the Dead Sea Scrolls: Proceedings of the Fourteenth International Symposium of the Orion Center for the Study of the Dead Sea Scrolls and Associated Literature, 28-30 May, 2013, 140-55, Leiden: Brill.

MacDougal, R. (2014), 'Remembrance and the Dead in Second Millennium BC Mesopotamia', $\mathrm{PhD}$ thesis, University of Leicester. 
Machinist, P. (2006), 'Kingship and Divinity in Imperial Assyria', in G. Beckman and T. J. Lewis (eds), Text, Artifact, and Image: Revealing Ancient Israelite Religion, 152-88, Providence, RI: Brown Judaic Studies.

Mandler, J. M. (1992), 'How to Build a Baby: II. Conceptual Primatives', Psychological Review 99 (4): 587-604.

Markschies, C. (2016), Gottes Körper: Jüdische, christliche und pagane Gottesvorstellungen in der Antike, Munich: C. H. Beck.

Mazar, A. (2015), 'Religious Practices and Cult Objects during the Iron Age IIA at Tel Rehov and Their Implications Regarding Religion in Northern Israel', Hebrew Bible and Ancient Israel 4 (1): $25-55$.

Mazar, A., and N. Panitz-Cohen (2008), 'To What God? Altars and a House Shine from Tel Rehov Puzzle Archaeologists', Biblical Archaeology Review 34 (4): 40-76.

McDowell, C. L. (2015), The Image of God in the Garden of Eden: The Creation of Humankind in Genesis 2:5-3:24 in Light of mīs pî pīt pî and wpt-r Rituals of Mesopotamia and Ancient Egypt, Winona Lake, IN: Eisenbrauns.

Mettinger, T. N. D. (1995), No Graven Image? Israelite Iconism in Its Ancient Near Eastern Context, Stockholm: Almqvist \& Wiksell International.

Miller, J. L. (2004), Studies in the Origins, Development and Interpretation of the Kizzuwatna Rituals, Weisbaden: Harrassowitz Verlag.

Moore, S. D. (1996), God's Gym: Divine Male Bodies of the Bible, London: Routledge.

Morgan, J. (2016), 'Religion and Dual-process Cognition: A Continuum of Styles or Distinct Types?', Religion, Brain \& Behavior 6 (2): 1-18.

Niehr, H. (1997), 'In Search of YHWH's Cult Statue in the First Temple', in K. van der Toorn (ed.), The Image and the Book: Iconic Cults, Aniconism, and the Rise of Book Religion in Israel and the Ancient Near East, 73-95, Leuven: Peeters.

Noegel, S. B. (2015), 'The Egyptian Origin of the Ark of the Covenant', in T. E. Levy, T. Schneider, and W. H. C. Propp (eds), Israel's Exodus in Transdisciplinary Perspective: Text, Archaeology, Culture, and Geoscience, 223-42, Basel: Springer.

Nongbri, B. (2018), God's Library: The Archaeology of the Earliest Christian Manuscripts, New Haven, CT: Yale University Press.

Ornan, T. (2004), 'Idols and Symbols: Divine Representation in First Millennium Mesopotamian Art and Its Bearing on the Second Commandment', Tel Aviv 31: 90-121.

Otto, R. (1917), Das Heilige: Über das Irrationale in der Idee des Göttlichen und sein Verhältnis zum Rationalen, Breslau: Trewendt und Granier.

Oviedo, L. (2015), 'Religious Cognition as a Dual-Process: Developing the Model', Method and Theory in the Study of Religion 27 (1): 31-58.

Parmenter, D. M. (2009), 'The Bible as Icon: Myths of the Divine Origins of Scripture', in C. A. Evans and H. D. Zacharias (eds), Jewish and Christian Scripture as Artifact and Canon, 298-309, London: T\&T Clark.

Parry, D. W. (1996), '4QSam a and the Tetragrammaton', in S. D. Ricks and D. W. Parry (eds), Current Research and Technological Developments on the Dead Sea Scrolls, 106-25, Leiden: Brill.

Pennycook, G., J. A. Fugelsang and D. J. Koehler (2015), 'What Makes Us Think? A Three-Stage Dual-Process Model of Analytic Engagement', Cognitive Psychology 80 (1): 34-72.

Polaski, D. C. (2007), 'What Mean These Stones? Inscriptions, Textuality and Power in Persia and Yehud', in J. L. Berquist (ed.), Approaching Yehud: New Approaches to the Study of the Persian Period, 37-48, Atlanta, GA: Society of Biblical Literature. 
Pongratz-Leisten, B. (2011), 'Divine Agency and Astralization of the Gods in Ancient Mesopotamia', in B. Pongratz-Leisten (ed.), Reconsidering the Concept of Revolutionary Monotheism, 137-87, Winona Lake, IN: Eisenbrauns.

Pongratz-Leisten, B., and K. Sonik (2015), 'Between Cognition and Culture: Theorizing the Materiality of Divine Agency in Cross-Cultural Perspective', in B. Pongratz-Leisten and K. Sonik (eds), The Materiality of Divine Agency, 3-69, Berlin: De Gruyter.

Porter, B. N. (2009), 'Blessings from a Crown, Offerings to a Drum: Were There NonAnthropomorphic Deities in Ancient Mesopotamia?', in B. N. Porter (ed.), What Is a God? Anthropomorphic and Non-Anthropomorphic Aspects of Deity in Ancient Mesopotamia, 15394, Winona Lake, IN: Eisenbrauns.

Pyysiäinen, I. (2009), Supernatural Agents: Why We Believe in Souls, Gods, and Buddhas, Oxford: Oxford University Press.

Radner, K. (2005), Die Macht des Namens: Altorientalische Strategien zur Selbsterhaltung, Wiesbaden: Harrassowitz Verlag.

Richardson, S. (2012), 'The Hypercoherent Icon: Knowledge, Rationalization, and Disenchantment at Nineveh', in N. N. May (ed.), Iconoclasm and Text Destruction in the Ancient Near East and Beyond, 231-58, Chicago, IL: Oriental Institute of the University of Chicago.

Roazzi, M., M. Nyhof and C. Johnson (2013), 'Mind, Soul and Spirit: Conceptions of Immaterial Identity in Different Cultures', International Journal for the Psychology of Religion 23 (1): $75-86$.

Roth, A. M. (1992), 'The Pš̌-kf and the "Opening of the Mouth" Ceremony: A Ritual of Birth and Rebirth', Journal of Egyptian Archaeology 78 (1): 113-47.

Sanders, S. (2008), 'Writing and Early Iron Age Israel: Before National Scripts, Beyond Nations and States', in R. E. Tappy and P. Kyle McCarter (eds), Literate Culture and Tenth-Century Canaan: The Tel Zayit Abecedary in Context, 97-112, Winona Lake, IN: Eisenbrauns.

Sanders, S. (2010), The Invention of Hebrew, Urbana, IL: University of Illinois.

Sanders, S. (2012), 'Naming the Dead: Funerary Writing and Historical Change in the Iron Age Levant', MAARAV 19 (1-2): 11-36.

Sanders, S. (2013), 'The Appetites of the Dead: West Semitic Linguistic and Ritual Aspects of the Katumuwa Stele', Bulletin of the American Schools of Oriental Research 369: 35-41.

Sanders, S. (2019), 'Words, things, and death: The rise of Iron Age literary monuments'. in R. Yelle, C. Handman and C. Lehrich (eds), Language and Religion, 327-49, Berlin: De Gruyter.

Schaper, J. (2007), 'The Living Word Engraved in Stone: The Interrelationship of the Oral and the Written and the Culture of Memory in the Books of Deuteronomy and Joshua', in S. C. Barton, L. T. Stuckenbruck and B. G. Wold (eds), Memory in the Bible and Antiquity: The Fifth Durham-Tübingen Research Symposium (Durham, September 2004), 9-23, Tübingen: Mohr Siebeck.

Scheyhing, N. (2018), 'Fossilising the Holy: Aniconic Standing Stones of the Near East', in L. D. Nebelsick, J. Wawrzeniuk and K. Zeman-Wiśniewska (eds), Sacred Space: Contributions to the Archaeology of Belief, 95-112, Warsaw: University of Warsaw.

Schleicher, M. (2010), 'Accounts of a Dying Scroll: On Jewish Handling of Sacred Texts in Need of Restoration or Disposal', in K. Myrvold (ed.), The Death of Sacred Texts: Ritual Disposal and Renovation of Texts in World Religions, 11-29, London: Routledge.

Schmid, K. (2012), 'The Canon and the Cult: The Emergence of Book Religion in Ancient Israel and the Gradual Sublimation of the Temple Cult', Journal of Biblical Literature 131 (2): 289-305. 
Schniedewind, W. M. (2009), 'Calling God Names: An Inner-Biblical Approach to the Tetragrammaton', in D. A. Green and L. S. Lieber (eds), Scriptural Exegesis: The Shapes of Culture and the Religious Imagination. Essays in Honour of Michael Fishbane, 74-86, Oxford: Oxford University Press.

Sharifian, F., R. Dirven, N. Yu and S. Niemeier, eds (2008), Culture, Body, and Language: Conceptualizations of Internal Body Organs across Cultures and Languages, Berlin: de Gruyter.

Smelik, W. F. (1999), 'The Rabbinic Reception of Early Bible Translations as Holy Writings and Oral Torah', Journal for the Aramaic Bible 1: 249-72.

Smith, M. S. (2008), God in Translation: Deities in Cross-Cultural Discourse in the Biblical World, Tübingen: Mohr Siebeck.

Smith, M. S. (2015), 'The Three Bodies of God in the Hebrew Bible', Journal of Biblical Literature 134 (3): 471-88.

Sommer, B. D. (2009), The Bodies of God and the World of Ancient Israel, Cambridge: Cambridge University Press.

Stager, L. E. (2008), 'The Canaanite Silver Calf', in L. E. Stager, J. D. Schloen and D. M. Master (eds), Ashkelon I, 577-80, Winona Lake, IN: Eisenbrauns.

Stavrakopoulou, F. (2013), 'Materialism, Materiality, and Biblical Cults of Writing', in K. J. Dell and P. M. Joyce (eds), Biblical Interpretation and Method: Essays in Honour of John Barton, 223-42, Oxford: Oxford University Press.

Stavrakopoulou, F. (2016), 'Religion at Home: The Materiality of Practice', in S. Niditch (ed.), The Wiley Blackwell Companion to Ancient Israel, 347-65, Chichester: John Wiley \& Sons.

Steiner, R. C. (2015), Disembodied Souls: The Nefesh in Israel and Kindred Spirits in the Ancient Near East, with an Appendix on the Katumuwa Inscription, Atlanta, GA: Society of Biblical Literature.

Suriano, M. J. (2014), 'Breaking Bread with the Dead: Katumuwa's Stele, Hosea 9:4, and the Early History of the Soul', Journal of the American Oriental Society 134 (3): 385-405.

Taylor, J. H. (2001), Death and the Afterlife in Ancient Egypt, Chicago, IL: University of Chicago Press.

Tigay, J. H. (1982), 'On the Meaning of Ț(W)ṬPT', Journal of Biblical Literature 101 (3): 321-31.

Tilford, N. L. (2017), Sensing World, Sensing Wisdom: The Cognitive Foundations of Biblical Metaphors, Atlanta, GA: Society of Biblical Literature.

Toorn, K. van der (1997a), 'Worshipping Stones: On the Deification of Cult Symbols', Journal of Northwest Semitic Languages 23 (1): 1-14.

Toorn, K. van der (1997b), 'The Iconic Book: Analogies between the Babylonian Cult of Images and the Veneration of the Torah', in K. van der Toorn (ed.), The Image and the Book: Iconic Cults, Aniconism, and the Rise of Book Religion in Israel and the Ancient Near East, 229-48, Leuven: Peeters.

Tov, E. (2004), Scribal Practices and Approaches Reflected in the Texts Found in the Judean Desert, Leiden: Brill.

Uehlinger, C. (1997), 'Anthropomorphic Cult Statuary in Iron Age Palestine and the Search for Yahweh's Cult Image', in K. van der Toorn (ed.), The Image and the Book: Iconic Cults, Aniconism, and the Rise of Book Religion in Israel and the Ancient Near East, 97-155, Leuven: Peeters.

Wagner, A. (2010), Gottes Körper: Zur alttestamentlichen Vorstellung der Menschengestaltigkeit Gottes, Gütersloh: Gütersloh Verlagshaus. 
Walker, C., and M. B. Dick (1999), 'The Induction of the Cult Image in Ancient Mesopotamia: The Mesopotamian mis pî Ritual', in M. B. Dick (ed.), Born in Heaven Made on Earth: The Making of the Cult Image in the Ancient Near East, 55-121, Winona Lake, IN: Eisenbrauns.

Walker, C., and M. B. Dick (2001), The Induction of the Cult Image in Ancient Mesopotamia: The Mesopotamian Mìs Pî Ritual, Helsinki: Neo-Assyrian Text Corpus Project.

Watts, J. W. (2016), 'From Ark of the Covenant to Torah Scroll: Ritualizing Israel's Iconic Texts', in N. MacDonald (ed.), Ritual Innovation in the Hebrew Bible and Early Judaism, 21-34, Berlin: De Gruyter.

Winter, I. J. (1992), “Idols of the King”: Royal Images as Recipients of Ritual Action in Ancient Mesopotamia', Journal of Ritual Studies 6 (1): 13-42.

Wyatt, N. (2012), 'After Death Has Us Parted: Encounters between the Living and the Dead in the Ancient Semitic World', in G. del Olmo Lete, J. Vidal and N. Wyatt (eds), The Perfumes of Seven Tamarisks: Studies in Honour of Wilfred G. E. Watson, 257-91, Münster: Ugarit-Verlag. Yasur-Landau, A. (2016), 'The Baetyl and the Stele: Contact and Tradition in Levantine and Aegean Cult', in E. Alram-Stern, F. Blakolmer, S. Deger-Jalkotzy, R. Laffineur and J. Weilhartner (eds), Metaphysis: Ritual, Myth and Symbolism in the Aegean Bronze Age, 415-19, Leuven: Peeters.

Zevit, Z. (2001), The Religions of Ancient Israel: A Synthesis of Parallactic Approaches, London: Continuum.

Zukerman, A. (2012), 'A Re-Analysis of the Iron Age IIA Cult Place at Lachish', Ancient Near Eastern Studies 49: 24-60. 